\title{
PENDEKATAN FILSAFAT ISLAM DALAM PENGEMBANGAN ILMU-ILMU KEUSHULUDDINAN
}

\author{
M. Zainal Abidin \\ Fakultas Ushuluddin dan Humaniora \\ IAIN Antasari Banjarmasin \\ Diterima tanggal 3 Mei 2015 / Disetujui tanggal 1 Juni 2015
}

\begin{abstract}
Ushuluddin is a fundamental root of Islamic sciences. Unfortunately, in its development, Ushuluddin as a scientific thing is considered irrelevant to answer society problems. It will be understood Ushuluddin just tanght religious doctrine exclusively without communicating it to social problems now. Ushuluddin basically is built based on the spirit of faith, Islam, and ihsan through philosophical approach is expected to further enrich Ushuluddin science itself, which in turn is the Ushuluddin will be able to respond to the challenges of modernity. Ushuluddin Faculty as a specific place to learn Ushuluddin sciences is encouraged to contribute in Islamic development, especially in Islamic thinking. Although the faculty does not have a lot of students, but those who enter Ushuluddin must have excellent academic ability and expertise of religion above the average, in addition of course good morals. After all, this writing discussed about Islamic philosophical approach in developing Ushuluddin sciences.
\end{abstract}

Kata kunci: Filsafat Islam, Iman, Islam, dan Ihsan

\section{Pendahuluan}

Salah satu persoalan yang seringkali muncul ketika kita berbicara tentang ilmu-ilmu Ushuluddin (Ushuluddin sciences) bahwa ini adalah kawasan "langitan" yang jauh realitas riil yang terjadi di masyarakat. Disiplin ilmu klasik keushuluddinan seperti kalam, filsafat, dan tasawuf yang diwarisi dari ulama muslim terdahulu dipandang kurang atau tidak memiliki relevansi khusus dalam membantu umat Islam untuk memahami dan sekaligus bekal dalam menghadapi realitas kehidupan mereka seharihari.

Ilmu-ilmu keushuluddinan pada masa lampau barangkali lahir sebagai bentuk respon terhadap apa yang menjadi kebutuhan dan tantangan umat Islam saat itu, tetapi perubahan dan tantangan zaman yang berbeda menjadikan ilmu-ilmu tersebut kehilangan peran sentral. Fazlur Rahman melihat bahwa ilmu-ilmu keislaman (termasuk keushuluddinan) yang berkembang saat ini sebagai disiplin ilmu, sangat sedikit menghasilkan pikiran-pikiran ataupun gagasan baru. Isinya lebih banyak berupa pengulangan-pengulangan atau komentar terhadap suatu karya. ${ }^{1}$

Kurang atau tidak adanya relevansi khusus antara ilmu-ilmu keislaman dengan realitas yang berkembang masa kini telah menjadikan umat Islam kehilangan peran sentral dalam merespons tantangan modernitas. Hal inilah yang disebut oleh Shabbir Akhtar sebagai bukti utama dari kelumpuhan intelektual umat Islam yang berimbas pada kegagalan mereka dalam memberikan respons yang memadai terhadap tantangan-tantangan modernitas sekuler. Umat Islam, ujarnya, tidak kekurangan para apologis (pembela agama) atau teoritikus agama, namun secara bersama-sama mereka

${ }^{1}$ Lihat Fazlur Rahman, Islam and Modernity: Transformation of an Intellectual Tradition (Chicago and London: The University of Chicago Press, 1982), 37-38. 
telah gagal memberikan respons yang bernas dan mendasar terhadap modernitas. ${ }^{2}$

Implikasi nyata dari bentuk irrelevansi ilmu-ilmu Ushuluddin dengan kebutuhan masyarakat adalah semakin tidak diminatinya kajian-kajian yang berkembang di Fakultas Ushuluddin. Problema mendasar yang sering muncul dari perbincangan para penggiat ilmu-ilmu keUshuluddin adalah sepinya peminat pada bidang ilmu ini. Dalam pertemuan-pertemuan para pimpinan Fakultas Ushuluddin, persoalan langkanya peminat pada bidang ini menjadi isu yang terus menerus didiskusikan.

Bersamaan dengan semakin sepinya peminat, Fakultas Ushuluddin juga menghadapi tantangan yang tak kalah hebatnya, yaitu tuduhan atau sangkaan bahwa Fakultas Ushuluddin dipandang turut berkontribusi dalam melahirkan pemikiran-pemikiran yang sekular yang menjadi "musuh" umat Islam, sehingga pandangan sinis terhadap fakultas ini semakin mengemuka. Kasus-kasus parsial yang terjadi di beberapa Fakultas Ushuluddin di Jawa digeneralisir sebagai karakter umum dari Fakultas Ushuluddin di Indonesia.

Persoalan krusial yang dihadapi Fakultas Ushuluddin dewasa ini berupa irrelevansi keilmuan yang berdampak pada langkanya peminat dan tuduhan miring sebagai pabrik pemikiran sekuler, mestinya membuat kita sebagai penggiat ilmu-ilmu keushuluddin untuk melakukan kritikan diri: apa yang terjadi dengan keilmuan Ushuluddin dan mau dibawa kemana (qua vadis) fakultas ini?

Tulisan ini mencoba melakukan kajian reflektif terhadap keilmuan Ushuluddin sebagai upaya untuk membangun keilmuan ini yang sesuai dengan kebutuhan umat Islam. Secara lebih spesifik, tulisan ini berupaya menempatkan filsafat Islam sebagai acuan dalam penyusunan kajian yang dikembangkan di Ushuluddin, yang diharapkan memiliki relevansi terhadap upaya pembangunan ilmu keushuluddinan yang relevan dengan perkembangan dan tantangan umat Islam masa kini.

\section{Rethinking Ilmu-ilmu Keushuluddinan}

Secara kebahasaan, istilah Ushuluddin berasal dari dua kata yakni ushûl dan dîn. Ushôl yang berarti dasar dan dîn berarti agama, sehingga dapat dimaknai Ushuluddin sebagai dasar-dasar agama. Secara historis, masih belum dapat dipastikan kapan penggunaan istilah Ushuluddin muncul pertama kali dalam ranah ilmu-ilmu keislaman. Hanya, dalam beberapa literatur klasik terdapat beberapa karya yang secara eksplisit menyebut tentang istilah Ushuluddin. Beberapa tulisan yang menyebut tentang Ushuluddin, yakni: 1). Ushuluddin karya Abu Manshur al-Baghdadi; 2) Asy-Syamil fi Ushuliddin karya al-Juwaini; 3). Ushuluddin karya Abu al-Yusr al-Bazdawi; 4) Tabsyirat al-Adilla fi Ushuliddin karya Abu al-Mun'im an-Nasafi (w. 1114); 5) Al-Mu'tamad fi Ushuliddin karya Qadhi Abu Ya'la; dan 6) AlMu'tamad fi Ushuliddin karya al-Malahimi al-Mu'tazili (w. 1141). ${ }^{3}$

Karya-karya dimaksud di atas yang merentang dari abad ke-9 sampai dengan $12 \mathrm{M}$ menyebut istilah Ushuluddin yang tidak lain dimaknai sebagai adalah ilmu kalam. Bahkan bisa ditegaskan bahwa Ushuluddin itu hanyalah nama lain dari ilmu kalam. Namun, dalam dalam pembidangan ilmu yang dilakukan LIPI, Ushuluddin atau dasar-dasar agama mencakup tiga bidang ilmu yakni ilmu tauhid/ kalam, filsafat Islam/tasawuf, dan perbandingan agama. ${ }^{4}$ Pada prakteknya di Indonesia, pembidangan ini tidak lagi relevan, dan kenyataannya nomenklatur jurusan pada fakultas Ushuluddin tidak lagi

${ }^{2}$ Lihat Shabbir Akhtar, Islam Agama Semua Zaman (Faith for All Seasons: Islam and Western Modernity), terj. Rusdi Djana (Jakarta: Pustaka Zahra, 2002), 7.

${ }^{3}$ Muhyar Fanani, "Reorientasi Kajian Ushuluddin dalam Merespons Tantangan Zaman", Jurnal Ilmu Ushuluddin, Vol. 13, No. 1, Januari 2014, 2.

${ }^{4}$ Fanani, "Reorientasi Kajian Ushuluddin, 3. 
dibatasi hanya 'kalam' sebagaimana istilah awalnya atau pada tiga bidang ilmu sebagaimana kreasi LIPI, tetapi telah mengalami perubahan.

Dalam kasus di Indonesia, kajian keislaman secara formal pada level perguruan tinggi dilakukan di antaranya oleh lembaga yang dinamakan Institut Agama Islam Negeri (IAIN). Hal ini dapat dilihat misalnya dari maksud dan tujuan pendirian IAIN sebagaimana pernah disampaikan pada 24 Agustus 1960/ 2 Rabi’ul Awwal 1380 H, yaitu: “Untuk memberi pengajaran dan menjadi pusat untuk memperkembangkan dan memperdalam ilmu pengetahuan tentang agama Islam.” Selanjutnya, dalam Peraturan Presiden No. 11 tahun 1960, pasal 2 disebutkan bahwa: "Institut Agama Islam Negeri tersebut bermaksud untuk memberi pengajaran tinggi dan menjadi pusat untuk memperkembangkan dan memperdalam ilmu pengetahuan tentang agama Islam." 5

Kalau kajian Islam dibagi menjadi dua kelompok yaitu kelompok dasar dan kelompok cabang maka Fakultas Ushuluddin memiliki tanggung jawab besar dalam mengelola dan mengembangkan ilmu keislaman pada kelompok dasar melalui kajian-kajian ilmiah.Pada kelompok dasar, ilmu keushuluddinan mencakup tafsir, hadis, akidah/ilmu kalam, filsafat Islam, tasawuf, tarekat, perbandingan agama serta perkembangan modern (pembaruan). Namun pada realitasnya, kajian keushuluddinan tidak terbatas pada ilmu-ilmu ini saja, tetapi juga mencakup sejumlah disiplin ilmu sosial dan filsafat yang berkembang di Barat seperti kajian-kajian antropologi, sosiologi, psikologi, fenomenologi, sejarah agama, dan filsafat modern.

Munculnya kajian-kajian ini mendampingi kajian-kajian keislaman turut memperkaya khazanah pengetahuan dan wawasan yang berkembang di Fakultas Ushuluddin. Kekayaan khazanah pengetahuan yang berkembang di Fakultas Ushuluddin ini menjadikannya sebagai satu-satunya fakultas di lingkungan IAIN/UIN yang memiliki kajian yang luas dan komprehensif mengenai kajian keislaman dan kajian sosial keagamaan serta kajian kefilsafatan. Dengan modal pengetahuan yang luas itu, maka kajiankajian keushuluddinan tidak hanya berkutat pada kajian-kajian Islam pada wilayah normatif tetapi juga berkembang ke wilayah Islam historis dan realitas agama dalam kehidupan masyarakat.

Sebagai ikhtiar untuk melakukan pengembangan kajian di bidang ilmu-ilmu keushuluddinan, maka ada baiknya titik pijak kita adalah dari Islam itu sendiri. Dalam diskursus filsafat ilmu diketahui bahwa setiap ilmu memiliki objek material dan objek formalnya sendiri. Dua objek ilmu inilah yang membedakan antara ilmu satu dengan ilmu yang lain. Pertanyaannya apa yang menjadi objek material dan objek formal ilmu Ushuluddin?

Apabila Islam yang menjadi pijakan untuk pengembangan ilmu, maka jelas bahwa objek material ilmu dalam Islam meliputi tiga pilar yang menjadi dasar tegaknya Islam sebagai sebuah agama. Ketiganya adalah Iman, Islam, Ihsan. Ilmu yang terkait dengan Iman dinamakan aqidah. Ilmu yang terkait dengan pilar kedua disebut syari'ah. Sementara ilmu yang berhubungan dengan pilar ketiga disebut ihsan/ akhlaq.

Selanjutnya, apabila objek material ilmu adalah Iman, Islam, Ihsan, maka apa yang menjadi objek formalnya? Mengacu pada karya-karya ulama masa lampau tentang Ushuluddin, maka dapat dijelaskan bahwa objek formalnya adalah pemikiran yang mendasar, radikal, tuntas, baik dengan cara dialektis (debat, jadal), maupun demonstratif (pembuktian) terhadap tiga pilar di atas atau yang terkait dengan ketiganya. Dengan kata lain perspektif filsafat menjadi spirit dalam pengkajian ilmuilmu keuhsuluddinan baik pada level Iman, Islam, maupun Ihsan.

${ }^{5}$ Akh. Minhaji dan Kamaruzzaman, Masa Depan Pembidangan Ilmu di Perguruan Tinggi Agama Islam (Yogyakarta: Ar Ruzz, 2003), 39-40. 
Bila kajian yang mendasar, radikal, tuntas, dialektis, demontratif tentang tiga pilar itu baru dinamakan kajian Ushuluddin, maka kajian tentang tiga pilar itu yang tidak dilakukan secara mendasar, radikal, tuntas, dialektis, demontratif bukanlah kajian Ushuluddin. Namun, kajian yang mendasar terhadap selain tiga pilar itu masih bisa dinamakan Ushuluddin asal dilakukan dengan menggunakan objek formal Ushuluddin. ${ }^{6}$

\section{Pendekatan Filsafat Islam}

Sebagaimana paparan sebelumnya bahwa pengembangan kajian keushuluddinan dapat dimulai dengan kajian filosofis terhadap tiga aspek mendasar dari Islam, yakni: Iman, Islam, dan Ihsan. Ketiga pilar ini bagi umat Islam merupakan pokok atau esensi yang menjadi asas dari agama Islam. Pertanyaannya bagaimana pengembangan ilmu, khususnya keushuluddinan dapat dilakukan melalui ketiga pilar tersebut?

Iman secara kebahasaan dimaknai sebagai kepercayaan atau keyakinan. Dalam doktrin umum teologi Islam, iman dimaknai sebagai keyakinan kepada Allah, malaikat, kitab, para rasul, hari akhir, dan qadha serta qadar Tuhan yang berlaku atas manusia. Sementara Islam dimaknai sebagai kepasrahan, berserah diri, tunduk, selamat, sejahtera, dan seterusnya. Rukun Islam dimanifestasi dalam bentuk syahadat, shalat, zakat, puasa, dan haji. Kelima rukun ini merupakan bentuk manifestasi konkret perwujudan dari sikap tunduk kepada Tuhan yang merupakan makna dasar dari Islam. Adapun Ihsan dimakni sebagai kebaikan. Ihsan dalam pemahaman umum dijelaskan sebagai bentuk perasaan akan kehadiran Tuhan. Engkau menyembah Tuhan seolah-olah engkau melihatnya, meski engkau tidak mampu melihatnya, yakinlah bahwa Tuhan itu melihat engkau.

Ketiga pilar Islam di atas, yakni Iman, Islam, dan Ihsan selain dipahami secara teologis, dapat dikembangkan lebih jauh lagi, khususnya terkait dengan upaya pengembangan keilmuan. Pengembangan ini tentu saja harus didasarkan pada sebuah pemahaman bahwa Islam itu tidak sematamata agama yang menyangkut hubungan seorang hamba dengan Tuhannya semata, tetapi lebih luas dari itu, bahwa Islam adalah sebuah juga peradaban (al Islâm huwa ad-dîn wa al hadharah). Sebagai sebuah peradaban, konstruksi Islam membutuhkan dasar atau fondasi yang harus lebih kokoh lagi. Terlebih apabila hal tersebut dikaitkan dalam upaya menjadikan Islam sebagai cara pandang terhadap realitas yang akan melahirkan Islam yang rahmat bagi seluruh alam.

Iman sebagaimana paparan sebelumnya bermakna keyakinan. Untuk mendapatkan keyakinan yang mantap jelas membutuhkan ilmu yang memadai sebagai argumentasi (burhân) terhadap hakikat dari apa yang diyakin tersebut. Dari perspektif filsafat, pembicaraan tentang persoalan hakikat sesuatu menjadi ranah ontologi. Filsafat Islam klasik banyak berbicara tentang metafisika atau ontologi (alwujud ). Bahkan, filsafat Islam sendiri didefinisikan oleh para penggiatnya pada masa dahulu seperti al Kindi sebagai ilmu tentang hakikat segala sesuatu (ilmu al asyyâ bi haqâiqiha). ${ }^{7}$ Secara lebih spesifik, sesuatu yang ada tersebut dibagi dalam tiga persoalan besar: masalah ketuhanan, kealaman, dan kemanusiaan. Pemahaman mendalam tentang hakikat trilogi metafisika di samping dipandang dapat membangun fondasi keimanan yang mantap, juga berguna sebagai cara pandang Islam terhadap realitas. Karena sebagaimana iman merupakan fondasi dasar, maka dalam pengembangan ilmu, aspek ontologi diyakini memberikan pengaruh yang sangat besar terhadap aspek yang lain, yakni epistemologi dan

${ }^{6}$ Fanani, "Reorientasi Kajian Ushuluddin, 5.

${ }^{7}$ Abdul Mu'thi Muhammad Bayumi, Madkhal ila Dirâsah al-Falsafah al-Islâmiyyah (Kâhirah: Kulliyah Ushûluddîn, 1998), 
selanjutnya aspek aksiologi.

Secara kebahasaan, Islam berasal dari akar kata aslama yuslimu, yang artinya: tunduk, patuh, damai, dan selamat sejahtera. Secara istilah diartikan sebagai ketundukan kepada kehendak Allah swt. agar mencapai keselamatan, kesejahteraan, kedamaian, baik di dunia maupun di akhirat. Prosesnya disebut Islam dan pelakunya kemudian dinamakan muslim. Dalam hal ini, kehendak Allah dijabarkan dalam tiga macam ayat (tanda-tanda) yang berbeda tetapi saling melengkapi; yakni: 1). Ayat-ayat qauliyyah, yaitu tanda-tanda kebesaran Allah yang ada dalam Alquran dan hadis sahih; 2). Ayat-ayat kauniyyah, yaitu tanda-tanda kebesaran Allah yang ada di jagat raya; dan 3).Ayat-ayat insâniyyah, yakni tanda-tanda kebesaran atau hukum-hukum Allah yang berlaku dalam mengatur kehidupan manusia. Berislam secara kaffah tentu menghendaki keyakinan dan pemahaman yang menyeluruh terhadap tanda-tanda kekuasaan Allah, baik yang terdapat pada ayat-ayat qauliyyah (wahyu) maupun ayat-ayat kauniyyah (alam raya) dan ayat-ayat insâniyyah (manusia). Semua berasal dari Tuhan, sehingga keilmuan yang berkembang juga berorientasi pada ketuhanan.

Dengan mendasarkan pandangannya pada Q.S. Fushshilat [41]: 53), Kuntowijoyomemiliki pandangan serupa dengan uraian di atas bahwa ilmu itu ada pada dasarnya dapat diklasifikasi pada tiga macam, yakni kauniyyah (ilmu-ilmu alam, nomothetic), qauliyyah (ilmu-ilmu Alquran, theological), dan nafsiyyah (ilmu-ilmu kemanusiaan, bermeneutical). Ilmu kauniyyah berkenaan dengan hukum alam, ilmu qauliyyah berkenaan dengan hukum Tuhan, dan ilmu nafsiyyah berkenaan dengan makna, nilai, dan kesadaran atau dikenal sebagai humaniora. ${ }^{8}$

Adanya tiga macam ilmu ini selaras dengan pemahaman umum dalam wilayah kajian epistemologi Islam bahwa ada tiga tanda-tanda (ayat-ayat) Tuhan yang dapat menjadi sumber ilmu, yakni: ayat-ayat qauliyyah yang potensial melahirkan ilmu-ilmu agama atau teologi; ayat-ayat kauniyyah yang potensial melahirkan berbagai disiplin ilmu kealaman; dan ayat-ayat insaniyyah yang potensial melahirkan ilmu-ilmu dalam bidang sosial-humaniora.

Kesadaran untuk memahami tanda-tanda kebesaran Tuhan yang ada dalam Alquran dan hadis sahih akan melahirkan berbagai kajian yang berhubungan dengannya. Sejarah Islam membuktikan betapa sangat kaya raya disiplin keilmuan yang berangkat dari kesadaran ini seperti tafsir, fiqh, ushul fiqh, kalam, dan lain sebagainya. Kesadaran untuk memahami tanda-tanda kebesaran Allah di jagat raya juga akan melahirkan berbagai disiplin keilmuan. Pengamatan terhadap gerak benda-benda angkasa melahirkan ilmu astronomi, pengamatan terhadap bebatuan menghasilkan geologi, demikian juga akan lahir darinya fisika, biologi, kimia, dan sebagainya. Kesadaran untuk memahami tanda-tanda kebesaran Allah pada diri manusia akan melahirkan berbagai disiplin ilmu-ilmu sosial dan humaniora seperti psikologi dengan cabang-cabangnya, kedokteran, dan berbagai jenis keilmuan lainnya termasuk tentunya di sini bidang keilmuan ekonomi, sosiologi, dan antropologi.

Paparan di atas menjelaskan bahwa keberislaman yang kâffah menghendaki kesadaran dan pemahaman pada berbagai tanda-tanda kekuasaan Allah baik yang terkait kitab suci, alam, ataupun manusia. Kesadaran ini tentu menuntut penyelidikan mendalam untuk semakin menguak tanda-tanda kebesaran Tuhan. Penyelidikan ini akan melahirkan disiplin-disiplin keilmuan yang beragam, namun tetap pada koridor yang sama, yaitu orientasi ketuhanan atau kesadaran ilahiah. Berangkat dari sini, pandangan yang hanya menempatkan ilmu-ilmu yang lahir dari wahyu Tuhan saja yang berhak menyandang sebagai anak yang sah dari peradaban Islam tidaklah relevan. Ilmu-ilmu alam dan ilmu 
sosial humaniora juga memiliki status yang sama, bagian yang sah dari ilmu-ilmu keislaman tentu sejauh ia tetap konsisten dalam visi ketuhanan.

Pada level ketiga, yakni Ihsan, dimaknai sebagai kebaikan. Dalam kajian filsafat, ini tentunya terkait dengan persoalan aksiologi. Aksiologi terkait dengan masalah penerapan. Kembali pada trilogi metafisika, maka hubungan yang harus terbangun dalam Islam mestilah pada tiga level sekaligus, yakni: hubungan baik kepada Tuhan, hubungan baik kepada alam sekitar, dan hubungan baik kepada sesama manusia. Ketiga hal ini melahirkan apa yang disebut dengan kesalehan individual yang berhubungan dengan Tuhan, kesalehan social yang berkaitan dengan sesama manusia, dan kesalehan alam yang menyangkut lingkungan atau makhluk hidup selain manusia.

Disiplin yang relevan dengan bidang ini adalah tasawuf/akhlak, karena pada tasawuf inilah banyak dibincangkan tentang akhlak terpuji dan tercela, yang tepat untuk menjadi basis nilai pengembangan ilmu. Tujuan tahapan akhir ini adalah untuk mengembangkan wawasan batin, menembus dimensi yang transendental-spiritual, dan mengantarkan pengalaman spiritual manusia ke dimensi yang Ilahi sebagai proses menuju mi'raj. ${ }^{9}$ Filsafat sebagai basis akan memberikan wawasan dan landasan nilai-nilai dalam operasional ilmu. Adapun tasawuf/akhlak akan mengantarkan seseorang masuk ke dalam dimensi transendental, sebagai bagian dari manifestasi iman dan pengabdian diri terhadap Tuhannya.

Ketiga konsep di atas akan melahirkan struktur keilmuan Islam yang komprehensif, tidak hanya berbicara pada urusan hubungan dengan Tuhan, tetapi juga bagaimana hubungan dengan sesama manusia dan alam semesta. Dengan memaknai Iman, Islam, dan Ihsan sebagaimana penjelasan di atas, dapat menjadikan Islam tidak semata-mata sebagai agama dalam maknanya yang sempit, tetapi dapat menjadikan Islam sebagai worldview dalam melihat realitas. Dengan menggunakan alur berpikir Iman, Islam, dan Ihsan serta dipadukan dengan konstruksi filsafat ilmu, yakni ontologi, epistemologi, dan aksiologi dan dengan mengambil inspirasi pada trilogi metafisika serta tuntutan kepatuhan kepada tiga macam ayat Tuhan, yakni ayat qauliyyah, ayat kauniyyah, dan ayat insâniyyah, maka paradigma keilmuan Islam yang harus dibangun dalam upaya mengembangkan ilmu yang integralistik belum memadai kalau hanya mengapresiasi terhadap satu macam ayat saja berupaya ayat qauliyyah, dan mengabaikan ayat-ayat kauniyyah serta ayat-ayat insâniyyah.

Dalam konteks pembangunan ilmu keushuluddinan, reposisi filsafat Islam sebagai basis pengembangan sangatlah penting Sebagaimana dipaparkan sebelumnya di bagian awal tulisan ini, bahwa problem utama keilmuan di dunia muslim adalah adanya disparitas antara ilmu-ilmu yang berkembang di dunia Islam dengan tantangan yang dihadapi oleh umat Islam secara khusus dan umat manusia pada umumnya. Kesenjangan tersebut diperkokoh lagi dengan adanya dualisme ilmu; ilmu agama dan ilmu umum, yang masing-masing berjalan sendiri-sendiri tanpa saling menyapa.

Kesadaran adanya kesenjangan tersebut melahirkan berbagai gagasan untuk mewujudkan ilmu yang integralistik, yakni ilmu-ilmu Islam yang relevan dengan kebutuhan dan tantangan modernitas. Paradigma keilmuan integralistik berangkat dari pemahaman terhadap konsep tauhid yang memiliki implikasi pada tuntutan keharusan adanya kesatuan ilmu, yakni semua ilmu berasal dari Allah yang menghamparkan tanda-tanda (ayat-ayat) kuasa (hukum-hukum/aturan main) yang harus dicari dan ditelaah oleh manusia untuk kemudian dikembangkan dalam berbagai bidang ilmu.

${ }^{9}$ Lihat Musa Asy'arie, “Epistemologi dalam Perspektif Pemikiran Islam”, dalam M. Amin Abdullah dkk., Menyatukan Kembali Ilmu-ilmu Agama dan Umum (Upaya Mempersatukan Epistemologi Islam dan Umum) (Yogyakarta: Sunan Kalijaga Press, 2003), 33. 
Penempatan filsafat Islam sebagai basis pembangunan ilmu ini didasarkan pada pemahaman yang diyakini secara umum bahwa induk semua ilmu itu ada pada filsafat, dan khazanah keilmuan Islam sudah semestinya menjadikan filsafat Islam sebagai basis kajian ontologisnya. Dalam filsafat Islam, ada tiga persoalan yang menjadi bahasan utama, yakni persoalan ketuhanan (Ilâhijyah), persoalan kealaman (kauniyyah), dan persoalan kemanusian (insâniyyah) yang lazim disebut dengan trilogi metafisika. Ketiga persoalan, yakni Tuhan, Alam, dan Manusia akan berbuah kepada keyakinan tentang status ontologis pada masing-masing bagian tersebut yang selanjutnya menjadi objek pengembangan ilmu yang integralistik. Pada saat yang bersamaan, dilihat dari aspek teologis, diskusi sekitar hakikat Tuhan, alam, dan manusia akan menjadi fondasi pada penguatan iman seorang muslim.

Kajian ontologi pada tiga persoalan trilogi metafisika akan berpengaruh pada pembahasan mengenai aspek epistemologis, khususnya yang terkait pada sumber ilmu. Ada tiga sumber yang dituntut kepada umat Islam untuk dieksplorasi secara mendalam, yakni terkait dengan penguakan terhadap tanda-tanda keagungan Tuhan berupa ayat-ayat qauliyyah, ayat-ayat kauniyyah, dan ayat-ayat insâniyyah. Eksplorasi pada ketiga macam ayat tersebut akan menghasilkan beragam varian ilmu, yang semua memiliki makna spiritual yang kuat bahwa itu semua ditujukan untuk memahami tentang keagungan Tuhan. Dilihat dari aspek teologis, ini akan memperkokoh makna Islam sebagai sebuah bentuk kepatuhan dan ketundukkan kepada Allah swt., yang dalam hal ini dimanifestasikan kepada pemahaman terhadap ayat-ayat Tuhan, sehingga dapat menghasilkan kepatuhan (Islam) yang maksimal (kaffah). Adapun pada ranah aksiologis akan menghasilkan suatu pola hubungan yang harmonis dan

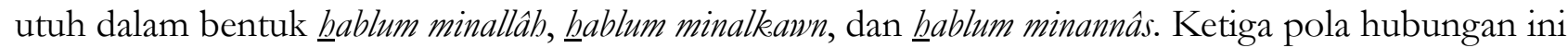
merupakan gambaran relasi yang harus dibangun oleh seorang muslim, dalam posisinya sebagai khalîfatullâh dan pada saat yang bersamaan sebagai 'abdullâh.

\section{Penutup}

Kembali kepada pokok persoalan sebagaimana dikemukakan pada bagian pendahuluan dari tulisan ini bahwa problema mendasar Ushuluddin yang saling bertalian adalah berakar dari irrelevansi keilmuan Ushuluddinan. Pengembangan keilmuan Ushuluddinan yang berpijak dari spirit Iman, Islam, dan Ihsan melalui pendekatan filsafat Islam diharapkan akan semakin memperkaya khazanah keilmuan Ushuluddin itu sendiri, yang pada gilirannya orang Ushuluddin - tidak sebagaimana sangkaan Shabbir Akhtar- akan mampu merespon tantangan modernitas secara benar. Fakultas Ushuluddin memang tidak perlu banyak mahasiswa, tetapi mereka yang masuk ke Ushuluddin haruslah mereka yang excellent (unggul) dan memiliki kemampuan akademik dan keahlian agama di atas rata-rata, di samping tentu saja akhlak karimah.

\section{DAFTAR PUSTAKA}

Abdullah, M. Amin, Islamic Studies di Perguruan Tinggi: Pendekatan Integratif-Interkonektif. Yogyakarta: Pustaka Pelajar. 2006.

Akhtar, Shabbir. Islam Agama Semua Zaman (Faith for All Seasons: Islam and Western Modernity), terj. Rusdi Djana. Jakarta: Pustaka Zahra. 2002.

Fanani, Muhyar. "Reorientasi Kajian Ushuluddin dalam Merespons Tantangan Zaman", dalam Jurnal Ilmu Ushuluddin. Vol. 13. No. 1. Januari 2014. 
Asy'arie, Musa. "Epistemologi dalam Perspektif Pemikiran Islam”, dalam M. Amin Abdullah dkk., Menyatukan Kembali Ilmu-ilmu Agama dan Umum (Upaya Mempersatukan Epistemologi Islam dan Umum). Yogyakarta: Sunan Kalijaga Press. 2003.

Bayumi, Abdul Mu'thi Muhammad. Madkhal ila Dirâsah al-Falsafah al-Islâmiyyah. Kâhirah: Kulliyah Ushûluddîn. 1998.

Kuntowijoyo. Islam Sebagai Ilmu: Epistemologi, Metodologi, \& Etika. Jakarta: Teraju. 2005.

Minhaji, Akh. dan Kamaruzzaman. Masa Depan Pembidangan Ilmu di Perguruan Tinggi Agama Islam. Yogyakarta: Ar Ruzz. 2003.

Rahman, Fazlur. Islam and Modernity: Transformation of an Intellectual Tradition. Chicago and London: The University of Chicago Press. 1982. 